REVIEW

\title{
Advances in Molecular Markers and Their Applications in Aquaculture and Fisheries
}

\author{
Hakim Mudasir Maqsood ${ }^{1}$, Syed Mudasir Ahmad ${ }^{1, *}$ \\ ${ }^{1}$ Sher-e-Kashmir University of Agricultural Sciences and Technology, Faculty of Veterinary Sciences and Animal Husbandry, \\ Division of Animal Biotechnology, Kashmir, India.
}

* Corresponding Author: Tel.: +91.849 1003154; Fax: +91.949 1272223;

Received 20 December 2016

E-mail: mudasirbio@gmail.com

Accepted 06 March 2017

\begin{abstract}
Although aquaculture management becomes challenging because of overuse, pollution and human activities reduced resources and genetic variations, current developments in molecular technology and genome programs have created an enormous evidence to be used for the genetic advancement of aquaculture. Over the past decade, using molecular markers showed polymorphism at the DNA level and played rising role in aquaculture. The utility of DNA markers has certified the hastiness in the exploration of fish germplasm. Various molecular markers present and their differences in principles, methodologies and applications still need careful consideration in selecting more useful marker for the successful management of aquaculture. In addition to the basic principles, necessities, pros and cons of various markers, this review also discusses their usage in different aspects of aquaculture; we provide an overview of the potential of various techniques of functional genomics like expressed sequence tags (EST), microarrays and RNA sequencing in aquaculture.
\end{abstract}

Keywords: Molecular markers, RFLP, RAPD, AFLP, microsatellites, SNP, mitochondrial DNA, microarray, RNA sequence, fisheries, aquaculture.

\section{Introduction}

All organisms owing to their cellular and environmental properties are subjected to mutations, which ultimately lead to genetic variations (polymorphism). These mutations if occur within a particular nucleotide sequence might alter the whole amino acid string of a protein, result in a functionally new variant. In comparison to their original (wild type) counterparts, these variants might hold an increased or decreased metabolic efficiency, might perform poor or even get a new function. Similarly, gene expression may be pretentious by certain mutations in the regulatory regions, which alter the magnitude, and even pattern of expression e.g. turn on or off, over or under expression of proteins in certain tissues at various developmental or physiological stages of an organism (Marsjan and Oldenbroek 2007). Consequently, DNA markers have been applied widely to validate pedigrees, monitor populations in wild, to exploit multiplicity in founder animals and to display inbreeding level in reproductively effective populations (Vandeputte et al., 2011); besides describe quantitative trait loci (QTL) (Huston et al., 2012). Genetic diversity among the population ultimately provides evidence to their life histories and scale of evolutionary segregation. Heritable variations are expressed as alterations in both the quality and quantity of alleles and gene arrangement on the chromosomes that are present within and among the basic populations (Williamson 2001). Molecular markers are in fact the powerful informational tools in hand which help us to reveal genetic rareness among individuals, species and populations (Davey et al., 2011). Even during practicing diverse aspects of aquaculture, molecular markers have provided valuable evidences like identification and discrimination of aquaculture stocks on genetic basis, examining the importance of onset and propagation of fish stocks in aquaculture, besides facilitating selection of breeding programs and evaluation of chromosomal and gene manipulations (Yue, 2014)

The aquaculture based fisheries management in most cases has been for the most part fruitful with the instant source of concern, for instance the large quantity and size of fish on hand during harvesting (Ward and Grewe 1995). Economically, this approach seems to be advantageous but in the end may result in the extermination of the respective populace. As part of a larger global concern, reduction of genetic resources in fish can in turn limit the genetic 
resources of the biosphere. It is therefore imperative to support molecular genetics for its indispensable role in sustainable management of fisheries genetic resources (Ovenden et al., 2014). This approach will address conservation of both gene pools and genetic diversity; two slightly different aspects of genetic resources. Therefore, to develop an optimal strategy for effective management of genetic resources, genetic characterization of fish species in wild is of vital significance. Such a strategy once adopted will ensure the greatest economic benefits on one hand and will help to sustain natural populations on the other hand (Allendorf et al., 1987). Fish biologists and aquaculturists should elucidate the significance of the factors and conditions; permitting maintenance of species and populations as such. Molecular tools, which are currently available, hold the promise of allowing identification of genes for traits like, adaptation, functional traits, growth, and disease resistance. This review discusses the development and use of these different types of molecular markers and examines the present status and future prospects in fisheries and aqua-farming.

\section{Glimpses of Molecular Markers and Polymorphism}

Markers are "character traits" whose inheritance patterns can be tracked at the morphological, biochemical (isozymes) or DNA levels. These characters are called markers because they are used to obtain information about the genetics of other traits of interest. Molecular markers have revolutionized genome analysis in all species of mammals especially in human beings and livestocks, including fish. Genetic markers, which control morphological traits by a single locus, are typically more useful, because expression pattern of these markers is reproducible over a wide array of environs and is visually detectable. Although co-dominant morphological markers are useful to distinguish the genotypes, an expression of such characters is largely influenced by environmental factors and modifying genes that might limit its usefulness as a genetic marker. It is believed that the influence of environment is the major disadvantage of morphological and biochemical markers, which tend to give unreliable results (Vithanage and Winks 1992). The limited genetic variability especially among the varieties of same species restricts the application of morphological markers. Biochemical polymorphisms were the first markers used in animal genetics. The limitation of such markers in genetic diversity studies is because of the fact that, polymorphism observed and the number of polymorphic loci assayed at particular loci is often low (Marsjan and Oldenbroek 2007). However, introduction of protein electrophoresis in later part of $19^{\text {th }}$ century proved an approach to solve difficult discriminatory problems by shifting from phenotype to molecular products (Wirgin and Waldam 1994).
This approach resulted in the earliest application of conservation and/or management of cultured fish species using genetic markers.

In some species when multiple forms adapted to different environments occur at the same place, which are maintained by natural selection are said to possess polymorphism. Another words it means the existence of two or more forms of an individuals within the same species or differences in DNA sequences among the individuals (Joshi et al., 2004). Polymorphism can be either transient or balanced. In transient polymorphism, a genetically managed condition is in the process that spreads throughout the population and ultimately leads to uniformity. Balanced polymorphism on the other hand involves two or more forms maintained at logical frequencies in the same population. The polymorphism present in natural populations differs markedly in different species (Charlesworth, \& Charlesworth, 2016). Sequencing or making restriction maps are often used to assess the grade of polymorphism. This information is generated in the characterization of mutant alleles at gene locus.

Comparatively, the stability and degree of polymorphism offered by DNA markers is elevated than usual morphological or protein (isoenzyme) markers (Stallen et al., 2000). Since genetic framework of a species is exclusive and remains unaffected by age, physiological conditions or the ecological factors, DNA markers are reliable for informative polymorphism. Understanding the nature of polymorphism may provide a base for developing strategies to exploit it for genetic purposes. For aquaculture purposes, a rapid molecular tool such as DNA barcode technique could be used to survey species membership verification, their composition and their differentiation from morphologically similar species (Spies et al., 2006; Hubert et al., 2012).

At present, low-density aquaculture species like, tilapia, catfish, giant tiger prawn, kuruma prawn, Japanese flounder and Atlantic salmon molecular marker maps have been constructed. In case of highdensity species like trout, marker map was published in 2003. According to a report by Nichols et al. (2003), vast majority of fish markers (1300 in number) spreading throughout their genome are AFLPs however, around 200 markers are microsatellite in origin. Various DNA-based techniques utilized to evaluate genetic diversity in aquaculture species can be organized into two main classes (Figure 1).

\section{Non-PCR Based Techniques}

Restriction Fragment Length Polymorphism (RFLP) markers (Botstein et al., 1980) marked the start of very different era in the biosciences, and as per Dodgson et al. (1997) are considered as the first shot in the genome revolution. In practice, RFLPs are recognized using restriction endonucleases that slice 


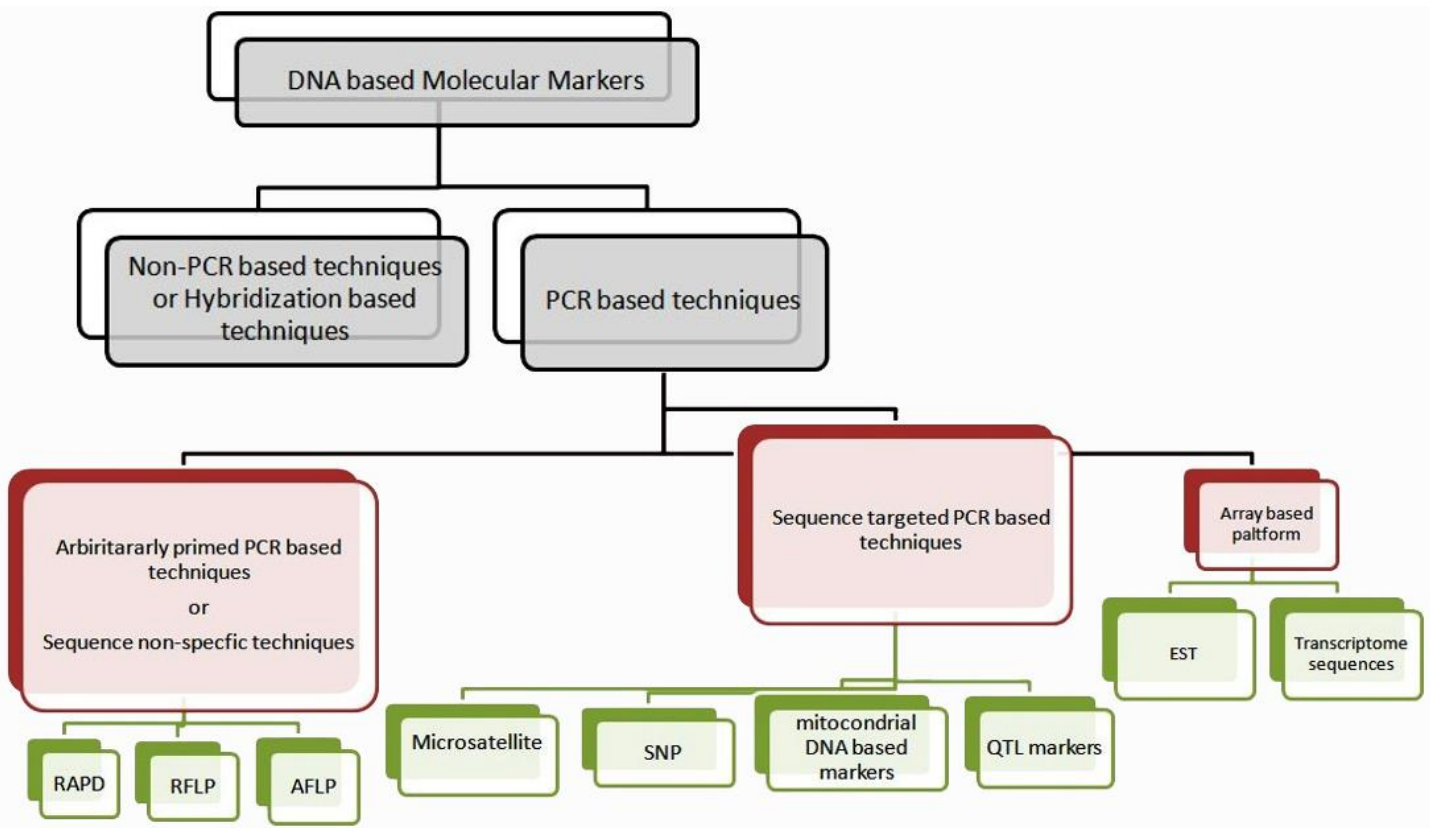

Figure 1. Molecular markers used in fisheries and aquaculture.

the DNA only at specific sites referred as "restriction sites". Digestion with a particular restriction enzyme yields DNA fragments of variable number and size among species and populations. Thus, results in polymorphic pattern of separation. The advantages of RFLP markers include relatively high polymorphism, co-dominant inheritance and high reproducibility. RFLP markers are considered better because of common incidence genome of plants in particular, elevated heritability and locus specificity. The method also provides prospect to monitor simultaneously numerous samples at the same time.

\section{PCR-Based Techniques}

The advancement of DNA magnification, using Polymerase Chain Reaction (PCR), a novel technique, unlocked the prospect of examining genetic changes in populations over the past 100 years or more. For simple understanding, PCR based techniques can be categorized into; (i) Randomly primed PCR-based procedures or sequence nonspecific methods and (ii) Sequence targeted PCR-based techniques, and (iii) Array Based Platforms.

\section{Random Amplified Polymorphic DNA (RAPD)}

Introduced in 1990, the technique uses in-vitro amplification arbitrarily to amplify the unknown loci of nuclear DNA with a matching pair of oligoprimers, usually $8-10$ base pairs (bp) in length (Welsh and McClelland 1990; Williams et al., 1990). RAPD technique evaluates the genetic disparity within or between the taxa of concern by assessing the occurrence or lack of each product, which is directed by alteration in the DNA sequence at each locus. The technique offers a simple, inexpensive but an efficient method of generating molecular data. Being highly polymorphic i.e. only a diminutive quantity of DNA is required with no prior comprehension about the genetic makeup of the individual (Hadrys et al., 1992). It is the main reason why the method has been successfully engaged in many phylogenetic and taxonomic studies (Sharma et al., 1995; Khan et al., 2000) and as such has been rather extensively in use in fisheries research. The major drawback left with this technique is that banding pattern is reliant on the reaction circumstances, which might fluctuate among different laboratories. Furthermore, an outcome amplification profile by each primer frequently includes several different loci within the genome, which essentially is unable to differentiate between heterozygous and homozygous individuals (Bardakci, 2001).

Mudasir et al. (2016) used RAPD markers for stock identification of Nemipterus japonicus. The technique has been extensively used for species identification in mollusks (Klinbunga et al., 2000; Crossland et al., 1993); and marine algae (Van Oppen et al., 1996). Bagley et al. (2001) utilized this method for investigation of genetic impact due to ecological stressors. Wolfus et al. (1997); Hirschfeld et al. (1999); Yue et al. (2002) are some of the excellent studies carried using RAPD in genetic diversity analysis.

Arbitrarily Primed Polymerase Chain Reaction (AP-PCR) and DNA Amplification Fingerprinting (DAF) techniques are variant methodologies of RAPD which have been developed independently. AP-PCR technique involves nonspecific amplification for initial two PCR cycles using a single primer (Welsh and McClelland, 1990). There after the remaining amplification is carried out at high stringency by rising the annealing temperature. 
Initially, this modification was not very popular among researchers as it implicated autoradiography but after amplification, fragments could be fractionated by means of agarose gel electrophoresis. The DAF procedure on the other hand uses single but random primers usually less than ten nucleotides for extension (Caetano-Anolles and Bassam 1993) and the ensuing amplicons are analyzed using polyacrylamide gel alongside with silver staining.

\section{PCR-Restriction Fragment Length Polymorphism (RFLP)}

Over the last decade, population makeup of fishes has been effectively studied for mitochondrial DNA (mtDNA) using RFLP, and frequently revealing more divergent genetic heterogeneity than isozyme analysis (Billington and Hebert 1991). Recent induction of PCR automation (Saiki et al., 1985) and multi-specific primers (Kocher et al., 1989; Meyer 1994) have promoted the effectiveness of the method by allowing mtDNA analysis to be carried out on selected segments of the mitochondrial genome even from tarnished or minute quantity of tissues. A number of commendable publications in this regard have come up in past (Chow et al., 1993; Cronin et al., 1993; Chapman et al., 1994; Giuffra et al., 1994). In recent years, species-identification techniques based on stable DNA molecules carrying the specific genomic information have gained recognition in food sciences, particularly fish origin. In view of its reliability, RFLP is standard technique used for genera, species or subspecies discrimination as studied in fishes by Quinteiro et al. (1998); Wolf et al. (2000); Russell et al. (2000).

\section{Amplified Fragment Length Polymorphism (AFLP)}

AFLP is a PCR based technique capable of generating multi-locus and reliable genomic fingerprints (Vos et al., 1995). Like RFLPs, the basic principle of AFLP polymorphism comprises insertion and deletion (indels) and substitution of nucleotides between and at restriction sites; similar to RAPD, it consists of base substitutions at primer binding sites during PCR. The technique in a way is unique because it allows the binding of adaptors of known sequences to DNA fragments generated by complete digestion of genomic DNA. Separation of fragments generated after subsequent amplification of subset of total fragments then becomes easy. Although the principal target is the identical as that of RFLP i.e. polymorphism but as an alternative of analyzing one locus at a time, it allows simultaneous study of numerous loci. Various advantages of AFLP technique can be summarized in following points.

No need for prior knowledge of any sequence information.

Multiple bands are produced per each experiment.

These bands are produced from all over the genome. 1998).

The technique is reproducible (Blears et al.,

Have high discriminatory power.

The data can be stored in database like AmpliBASE MT (Majeed et al., 2004) for comparison purposes.

Campbell et al. (2003) studied the effectiveness of AFLP, while differentiating the origin of an individual from a recognized populace; they found it to be more efficient than the microsatellite markers. Since greater part of AFLP fragments match up to matchless genomic positions, these can be looked at as landmarks in genetic and physical mapping. The technique can also be helpful at the sub-species level in differentiating closely related individuals, and can help in mapping genes (Althoff et al., 2007). Genetic research largely has been focused on evaluating and selecting better traits via cross breeding and interspecific hybridization (Bondari 1984; Dunham and Smitherman 1983; Hallerman et al., 1986; Wolters and Johnson 1994; Padi, 1995). To increase the selective competence especially for traits like disease resistance, feed conversion efficiency, and processing yields; researchers need to expedite the development of superior markers allied with genetic loci controlling economically viable traits of superior breed stocks (Waldbieser et al., 1998).

\section{Microsatellites}

These include tandemly arranged manifold copies of simple sequence repeats (SSRs) of 1-6 bps in their size (Tautz, 1989). Occurrence of microsatellites is very common in the entire the species studied to date, and in fishes, they subsist once every $10 \mathrm{kbs}$ (Wright, 1993). At the genomic level, microsatellites tend to be evenly disseminated on the entire chromosome i.e., both within gene coding part-introns (Liu et al., 2001c) as well as in the noncoding sequences. Depending on the number of base pairs in a repeat unit, microsatellites can be sub grouped into mono (e.g. C or A), di (e.g. CA), tri (e.g. CCA), tetra (e.g. GATA) repeat unit microsatellites. According, the short repeats of about 10-30 bases are microsatellites and longer repeats between 10-100 bases are minisatellites.

Since microsatellites loci are typically short, it is easy to amply them using PCR and subsequently analyzes the amplified products. Due to the lead of microsatellites in contrast to other molecular markers, they have gradually replaced allozymes and to some extent mtDNA.

For the reason that hyper-variability of microsatellites, these markers regularly show tens of alleles at a locus that differ from each other in the number of the repeats (Hoshino et al., 2012). They have been exploited for the conservation of fish 
germplasm, phylogenetic analyses, in breeding programs, construction of linkage maps, mapping economically important quantitative traits and identifying genes responsible for such traits. Microsatellites are still the markers of preference for studying multiplicity as well as parentage scrutiny; QTL mapping, although in the near future, their applicability may be tested with the development of SNPs.

\section{Single Nucleotide Polymorphism (SNP)}

SNP demonstrate polymorphism that result in different alleles as a consequence of point mutation caused by addition or deletion of single base at a particular nucleotide position within a locus. SNPs becoming center of attention in molecular marker development is because of the fact that these markers are most profusely identified in any organism's genome (coding and non-coding regions), revealing concealed polymorphism usually not identified with other markers and methods (Morin et al., 2004; Liu and Cordes 2004; Rasal et al., 2016). In the whole genome, the occurrence of SNPs is copious in noncoding regions. Within the coding regions, SNP is either non-synonymous resulting in an amino acid change (Sunyaev et al., 1999), or it is silent without altering the amino acid sequence, that can result in phenotypic changes by modifying mRNA splicing (Richard and Beckman 1995). Even though availability of complete genomic sequences for majority of candidate species in aquaculture is insufficient (Liu, 2011), but using next generation sequencing expertise, such as restriction siteassociated DNA sequencing (RAD-seq), SNP development can be made possible. According to Le Bras et al. (2011), SNPs can be potentially used for linkage mapping.

In aquaculture, SNPs are mostly used for genomic studies and identification of diagnostic markers for various diseases (Okumus and Ciftci 2003). Research pertaining to breeding programs like a) marker assisted genomic selection, b) QTL mapping and positional cloning, c) haplotype and pedigree analysis, d) variety identification and seed purity testing, and e) monitoring performance of different allelic combinations in target environs (Bernardo 2008; Kim et al., 2010; Moose and Mumm 2008; Mc Couch et al., 2010), find use of SNPs very promising and as such are considered next generation markers.

\section{Quantitative Trait Loci (QTL) Mapping}

QTLs are the regions within the genome that include genes associated with a particular trait, for instance growth, yield, adaptability to a particular environ, disease resistance. To identify QTL for essential traits in entire genome of the species of concern, the availability of linkage maps is essential to assist the selection of those desired traits. According to Yue 2013, in more than 20 aquaculture fish species, QTL for traits like cold and salinity, sex determination, growth and disease resistance have been mapped. Such studies can provide necessary information about patterns and the rate of evolutionary changes besides may provide tools for marker assisted selection (Groenen et al., 2000). Mapping typically results in differing crosses and segregation pattern analysis in the offspring of hybrids between the divergent crosses. The applied goal of mapping understood so far is to identify the position of specific phenotypic traits, which could be helpful in breeding programs. Mapping genes and QTLs is of fundamental and applied interest in aquaculture species. Yue (2013) mentioned polymorphic markers, genotyping platforms, reference families and software programs are prerequisite for constructing a linkage map of any species. The purpose of QTL mapping is to assist in selective breeding by understanding the effect and quantity of genes determining a trait (Naish and Hard 2008). QTL analysis for important traits like thermal tolerance, spawning time, embryonic development, growth traits, stress, salinity tolerance, infectious hematopoietic necrosis and bacterial cold-water disease have been conducted for more than 20 aquaculture species including finfish, mussels and crustaceans. QTL mapping is the practical application of marker-assisted selection in aquaculture (Sakamoto et al., 2000). Among the 20 species studied so far, tilapia and rainbow trout are among most important fresh water food fish species where salmons are the major cultured marine fish species (Gjedrem and Baranski 2009).

\section{Mitochondrial (mt) Marker}

DNA within mitochondria has been indispensably used in phylogenetics and bar-coding studies. mtDNA is inherited maternally except in edible oyster, it is haploid and has a high rate of mutation unlike nuclear genome it does not recombine and evolves more rapidly. In view of these characteristics, biologists have been able to reconstruct evolutionary relationships between and within species by assessing mutation patterns in mtDNA. The size of the mitochondrial genome in animals varies among different organisms, but typically the number is around 16,000-19,000 base pairs (bp) in teleost fish. In animals including fish, mtDNA encodes 13 proteins, 2 ribosomal RNAs, and 22 transfer RNAs (Boore, 1999). These genes are highly packed on the mitochondrial genome without introns. D-loop region is the highly polymorphic region making it useful for analysis of population genetics (Norman, 1994). mtDNA markers are in principle RFLP markers the only distinction is that target DNA is mitochondrial and not nuclear (Cronin et al., 1993). The analysis of mitochondrial markers is 
mostly RFLP analysis, or direct sequence analysis (Liu and Cordes 2004). Being highly polymorphic and ease of analysis, mtDNA has been very successful as markers in aquaculture and fisheries research. There are some excellent studies by Avise et al. (1986), Graves et al. (1992), Gold et al. (1993a), Chow et al. (1993), and Heist and Gold (1999), which emphasize the extensive use of mtDNA in stock structure analysis of fishes. Mitochondrial markers in part due to their use in brood-stock identification are widely accepted among aquaculture geneticists (Benzie et al., 2002). These markers also provide a brisk way of detecting hybridization between species or their sub-species (Nijman et al., 2003). The two major drawbacks of mtDNA markers are, one is the non-Mendelian inheritance, and the second is the proportion of the total genomic variation one can observe with mtDNA alone. Additionally, mtDNA markers are subject to similar problems that exist for other DNA-based markers. For example, in back mutation cases, nucleotide sites that have already undergone substitution are returned to their original state. Mutations taking place at the same site on the mtDNA in independent lineages and unparallel rates of heterogeneity at the same region can place limitations on the validity of using mtDNA for genetic studies. Recent studies have suggested that mtDNA can influence performance traits (Steele et al., 2008).

\section{Array Based Platforms}

Over the past few decades, the need for better throughput, reduced cost per data point and better map resolution lead to the evolution of molecular markers (Kumar, 1999; Gupta and Rustgi 2004). Essentially, microarray is a carefully constructed set of probes arrayed on some hard surface to which cellular cDNA copies of RNA are hybridized. Microarray technology provides a thoughtful insight about the temporal and spatial expression patterns of genes in reaction to a variety of factors to which an organism is exposed. It is a powerful tool to measure the expression pattern of innumerable genes simultaneously in an organism that ultimately helps to understand the Transcriptome and proteome as well. This approach might divulge the global patterns of expressed genes besides identify novel genes associated with phenotypic characteristics. Arcand et al. (2004), Gonzalez et al. (2004). Zhang et al. (2009) reviewed that microarray tool is a powerful method in fisheries research for rapid screening of genes or transcriptional profiles or for characterizing economically important traits for instance, genes linked to growth, feed conversation, disease management, etc.

In fisheries and/or aquaculture, DNA microarray exists in two fundamental platforms:

High Density Arrays or Expressed Sequence Tags (EST) include gene fragments spotted on the chip, providing a "ready to use chip" for analyzing the simultaneous expression of a relatively large number of genes.

Customized cDNA microarrays PCR amplified cDNA fragments or synthetic oligonucleotide based on ESTs spotted on glass slides or nylon membranes (Ju et al., 2007).

cDNA microarrays have been developed from manu fish species, for instance, cDNA libraries microarray with 4512 clones in zebra fish (Ton et al., 2002), 11060 clones spotted in duplicate in European flounder (Platichthys flesus) (Cohen et al., 2008), and a chip containing about 4500 features for the African cichlid fish, Astatotilapia burtoni (Renn et al., 2004). Similarly, salmonid microarray containing about 16006 cDNA has been used to study the transcriptomics response to fast-twitching muscle atrophy from gravid trout compared to those of sterile fishes (Ewart et al., 2005; Salem et al., 2006). These are all personalized microarrays. Furthermore, Panicker et al. (2004) developed a DNA microarray assay for the real-time detection of five marine fish pathogens viz., Vibrio vulnificus, V. anguillarum, $V$. parahaemolyticu, Photobacterium damselae and Aeromonas salmonicida. Further, three shellfish pathogens (i.e., Vibro vulnificus, V. cholerae, and $V$. parahaemolyticus) were detected by González et al. (2004) by developing a gene-specific DNA microarray. Studies by Rise et al. (2004); Sigh et al. 2004; Lindenstrom et al. (2006); Fast et al. (2006); Martin et al. (2006), unfold the use of microarray based expression patterns of target genes to investigate immune response, disease processes and resistance in salmonid.

Microarray have also been used to explore the response of rainbow trout transcriptome to chemical contaminants (Koskinen et al., 2004), toxicogenomic profiling of hepatic tumour promoters (Tilton et al., 2006), and gene expression in atrophying muscle (Salem et al., 2006). The application of DNA microarray in fish biology and aquaculture could have immense significance through discovery of novel genes, their expression profiles and response to various environmental stimulations at genome level.

\section{Expressed Sequence Tags (EST)}

Understanding genomes of fish species having aquaculture importance becomes critical in gaining detailed information about the performance and production traits. Although availability of approaches like serial analysis of gene expression (SAGE) has not diverted the attention of scientists from ESTs as desirable method in discovering target genes in aquaculture. Recently, several novel sequencing platforms have been developed allowing generation of expressed sequence tags via de novo sequencing of complete genomic transcriptome. EST sequencing has been one of the primary techniques employed for transcriptomics analysis in wide range of species 
including fishes (Liu, 2006). In full-length cDNA synthesis and gene sequencing, ESTs are considered important. It is among the most brisk molecular techniques for rapid identification of a large number of genes. By virtue of its remarkable rate of gene discovery, EST analysis has been exceptionally accepted. EST database have already been established in species like Atlantic salmon (Salmo salar) and oyster (Crassostrea gigas). Similarly, cDNAs and ESTs databases offering development of virtually no cost markers for Rainbow trout have been made available to public (Venkatesh et al., 2005). Comparatively, EST database has been one of the fastest mounting repository at NCBI. Species like Atlantic salmon, Rainbow trout, catfish, oysters and shrimps have established ESTs.

\section{Transcriptome Sequencing}

Transcriptomics specifically aims to: (1) register all transcripts in a framework of cell types for a species, including mRNAs, small and non-coding RNAs; (2) find out the transcriptional patterns of genes in terms of their start and end sites, splicing patterns and other post transcriptional modifications; and (3) measure transcript expression levels during development and varied physiological and pathological conditions (Liu et al., 2013). Recently RNA Sequencing (RNA-Seq) technique with far higher resolution than available with conventional Sanger sequencing and microarray based methods was developed besides eliminating numerous challenges posed by microarray technologies, including the limited dynamic range of detection. In this technique, next generation sequencing technologies are employed to sequence directly cDNAs generated from the RNA of interest. The reads so obtained can be aligned to reference genome to construct a whole genome transcriptome map. The applicability of high-throughput next generation DNA sequencing (NGS) technologies have altogether revolutionized the transcriptomics by allowing RNA analysis through cDNA sequencing at massive scale (Liu et al., 2013). In view of the importance of sequencing capabilities, such as throughput, read length, error rate and ability to perform paired reads for RNA-seq as well as genomic studies, NGS companies are constantly improving their platforms to provide the best sequencing performance at the lowest cost (Metzker, 2010). Based upon the different choices of sequencing technologies, sequencing yields and varying read lengths, RNA-seq data analysis involves two approaches. First approach engrosses mapping the resultant reads to a reference transcriptome while the second one adopts de novo assembly for species without the reference genome or reference transcriptome. Accordingly, a genomic scale map composed of both the transcriptional structure and expression level for each gene can be generated (Wang et al., 2009). Presently RNA-Seq is being widely used in functional genomics studies both in aquaculture and their related model species like

Zebrafish (Hegedus et al., 2009; Aanes et al., 2011; Ordas et al., 2011) catfish (Liu et al., 2013), Atlantic cod (Johansen et al., 2011), rainbow trout (Lewis et al., 2010; Salem et al., 2010), European eel (Coppe et al., 2010) and spotted gar (Amores et al., 2011). Salem et al., (2012) using RNA sequencing identified about 22 SNP markers and 1 mtDNA haplotype with growth traits in rainbow trout. Liu et al. (2013) studies whole genome transcriptome in rainbow trout exposed to various stress conditions using RNA sequencing. Although, most farmed fish lack a reference genome and in most cases the transcriptome information available is very scarce. However, this is not limiting for RNA-seq approaches which are powerful tools for de novo assembly and transcriptome profiling of different eukaryotes including non-model fish species (Coppe et al., 2010; Crawford et al., 2010; Surget- Groba and MontoyaBurgos 2010). The potential of RNA-seq for wholetranscriptome analysis has been demonstrated recently in zebrafish (Danio rerio), a well-established model for genetics and developmental biology with an annotated transcriptome of 16,416 genes. Genome sequencing of fishes and shell fishes contributes not only to the understanding of their evolution but also to environmental genomics and aquaculture (Crollius and Weissenbach 2005; Cossins and Crawford 2005).

\section{New Molecular Markers Made Available in Aquaculture Species}

In aquaculture, DNA markers for species like catfishes, tilapias, salmonids, shrimps, and oysters are being development as part of a regional project (NE186) in USA, now a part of National Project NRSP-8. Similar efforts are also going for striped bass. Similarly, a lot of progress has been made in the development of microsatellite markers in Atlantic Salmon (Houston et al., 2012), catfishes (Liu 2003; 2001c; Tan et al., 1999) tilapias (Carleton et al., 2002; Palti et al., 2001; Streelman and Kocher 2002; Cnaani et al., 2002), Penaeid shrimps (Xu et al., 1999), common carp (Tanck et al., 2001) and chinook salmon (Williamson et al., 2001; Naish and Park 2002). Likewise, AFLPs for species like channel catfish and blue catfish (Liu et al., 1998b, 1999c), rainbow trout (Young et al., 1998) and oysters (Li and Guo 2004; Yu and guo 2003); RAPDs for catfish (Liu et al., 1998a, 1999b) and Asian arowana (Yue et al., 2002); and SNPs for catfish (He et al., 2003b) have been developed.

\section{DNA Markers; Their Application in Aquaculture Genetics}

In fishes, elementary problem is the correct identification of stocks species which ultimately lead to the idea of defining stock management (Carvalho 
and Hauser 1995). Requirement in any long-term culture programme is the identification and discrimination of stocks on genetic basis. To avoid the deleterious effects of inbreeding, crossbreeding of fishes from genetically different strains is of critical importance. This can be done effectively if data about genetic similarity and disparity is available especially when pedigree information is altogether lacking (Ferguson 1994), at the same time, genetic markers can be suitable for evaluating the variation between aqua cultured stocks and wild populations and attending to concerns about escapes or discharges from aquaculture farms in to natural population. Another application is the development of genetic tags, which breeders could utilize to safeguard their proprietary rights over their products.

Since fishes show surprising diversity in terms of their shape, size and color, their correct identification is not only of interest for taxonomy and systematic but also a requirement in studying their natural history and ecology, management, tracking dispersal patterns of eggs and larvae, estimation of recruitment and spawn areas and identification of food (Rasmussen et al., 2009). This information is very important for ecological monitoring, environmental impact assessment, and compensation of fisheries, resource management and conservation, prevention of smuggling and establishment of marine protected areas (Rasmussen et al., 2009).

\section{Assessment of Genetic Manipulations}

Genetic manipulation of fishes can be assessed by an array of methods like, polyploidy and gynogenesis, but genetic markers are invaluable for its successful confirmation. Owing to the high polymorphism of microsatellite markers, triploidy, for instance can be confirmed, because of the high polymorphism of the said markers, which makes it possible to observe three allele genotypes at certain loci. Single-locus markers like, VNTR loci work ideally for such assays (Ferguson 1994). Highly polymorphic genetic markers can also be used for assessing the level of homozygosity, which is expected to be complete in the case of mitogynes thus differentiating meiogynes from mitogynes. In aquaculture, molecular markers can further be applied in sex determination in case of monosex populations produced by sex reversal of females into males (masculinization) (Devlin et al., 1991). In transgenic fishes, introduced genes are tracked i.e., the assessment of integration, their expression and transmission, is done by methods utilizing nuclear DNA.

\section{Interspecific Variations}

Interspecfic and intergenic hybridization occurs to great extent in nature including both freshwater as well as marine fishes. The real number of hybrids in nature may well be much higher than the number of hybrids actually known to investigators or identified correctly. When genetically differentiated individuals or groups are mated involving crosses within a species (also known as line crossing or strain crossing) or crosses between separate species, hybridization is said to have occurred. The breeding technique has gifted aqua culturists a hand on technique to produce aquatic organisms with desirable traits or general improvement in performance. Generally, the desired goal for any aquaculturist is to generate seed that can perform better than their parental stock (hybrid vigor or positive heterosis) in terms of different desirable traits. Hybridization also may be used to diffuse other advantageous features, e.g. disease resistance, from one species or group to another, to merge valuable traits from two species into a single one, e.g. good growth and fine quality of flesh, and to produce sterile individuals. The consequences of introgressive hybridization because of hetero-specific mating among species are frequently encountered in surveys of genetic diversity (Funk 2003). Introgressive hybridization results from the movement of DNA from one species to another species in the gene pool by repeated backcrossing of hybrid individuals with one or both parent species. According to Arnold (2009), this approach could be an important source of novel variations for a population less restrained by in situ mutation. However, it is difficult to say how often hybridization occurs within an individual group of closely related species. Further as has been observed heterospecific mitochondria might sometime invade the gene pool or even exchange the native mtDNA of a species subsequent to hybridization (Funk 2003; Chan 2005; Nevado 2009), but the fraction of the nuclear genome that is actually affected has rarely been documented as such (Yatabe 2007). Comprehensive evolutionary theory demands key focus on these issues, particularly since the consequences of hybridization may go well beyond reinforcement to include hybrid speciation, adaptive radiation, adaptive introgression, and combination or disappearance of poorly isolated species (Mallet 2005; Arnold 2009).

In order to manage individual species effectively, identification of different species from a mixed catch becomes important. DNA markers are widely being accepted not only to obtain information about gene flow and allele frequencies in aquaculture practices but also to identify hybrids. The majority of the markers, which are used in inter- and intraspecific disparity, include RAPD for species and subspecies identification done in tilapia (Bardakci and Skibinski 1994), and iso-enzyme used in intraspecific variations in Sparidae species (Alarcón and Alvarez 1999). Similarly, Nijman et al. (2003) reported the use of mtDNA markers as an important tool in rapid detection of hybridization between species and subspecies of livestock.

The management of capture fisheries can be 
made easy by utilization of molecular and genetic approaches. For instance genetic characterization, genetic marking and identification of fish species, strains, lines, populations can help to maintain the fish stocks in natural environments. DNA marker technologies have the capacity to provide "diagnostic kits" to identify many important species and populations (Liu and Cordes 2004). Such technologies should be adapted for wider use in the characterization of wild fish species and their stocks that are captured by humans, because at some level those species might be depleted because of overexploitation. For endangered species and depleting stocks, genome technologies can characterize fish species even after it has been processed. This should provide greater levels of law enforcement. Consumers should also be protected to ensure that fish product is labeled accurately at the point of sale (Maldini et al., 2006). Genomics has a lot to offer in accurate disease diagnosis, development of fish vaccines, drug resistance and to ensure the safety of aquatic products. Existing technologies are practically capable of delivering immediate results. Genome research, through QTL mapping, SNP identification provides potential avenues for addressing some of the problems (diseases) that threaten aquaculture industry by mapping major genes responsible for disease resistance. Palti et al. (1999) reported use of MAS in brood stocks development, containing disease resistant genes and conceptually traditional hybridization could be used to allow their introgression (Liu et al., 2003). Vaccines for fish diseases need special attention, though their applications in aquaculture have some limitations (Lorenzen et al., 2002). One major difference is the large number of individuals in populations of farmed fish species and their relatively low individual value. The aquatic environment also poses technical difficulties. Genome research may allow development of more effective vaccines, including DNA vaccines (Kurath 2005) and can indirectly help to find effective vaccine delivery systems. Genome technologies should also provide means for monitoring drug resistance in fish pathogens. This is concern to scientific community, because countries that produce fish but have relaxed laws with respect to drug use in aquaculture could contribute to increases in drug resistance in many pathogens with zoonatic importance (Graslund and Bengtsson, 2001). Molecular markers also find application in estimating the genetic loss in hatcheries through comparison with wild counterparts. Genetic upgradation programmes thus can be planed for effective monitoring of farmed stocks against inbreeding loss. A major aspect of such studies is to address the assessment of farm escapes into the natural population and introgression of wild genome. For example, Perkins and Krueger 1993 studied the variation in Brook trout (Salvelinus fontinalis) stocked in naturalized lakes, and hatcheries in New York and Pennsylvania using allozyme expression. They reported, all wild-unstocked populations were highly differentiated and significantly different from each other and from hatchery samples. Similarly, genetic diversity was investigated using microsatellites in farmed and feral populations of the Atlantic salmon (Norris et al., 1999). Less genetic variability in terms of allelic diversity was found in farmed as compared to their natural source population. Diversity in allozymes and three microsatellite loci was assessed in populations of natural and cultured stocks of Sparus aurata (Palma et al., 2001) and Sparius auratus (Alarcon et al., 2004). The microsatellite heterozygosity values were high in wild, but lower in the cultured samples.

\section{Conclusion}

Molecular markers have revolutionized the biological science and fisheries and aquaculture is not an exception. The markers discussed above show diverse usage in the applied aquaculture and fisheries research. The growing applications are reflected by the frequency of related literature being published to different journals. A range of area in fisheries where these markers can be used as valuable tools are species identification, population size and structure, intra specific relationship, stock enhancement, hatchery management, selective breeding, systematic and evolutionary genetics, legal applications and many other. These molecular markers can prove fruitful in fields like fish nutrition and disease management programmes.

\section{References}

Aanes, H., Winata, C.L., Lin, C.H., Chen, J.P., Srinivasan, K.G., Lee, S.G., Lim, A.Y., Hajan, H.S., Collas, P., Bourque, G., Gong, Z., Korzh, V., Alestron, P.P., \& Mathavan, S. (2011). Zebra fish mRNA sequencing deciphers novelties in transcriptome dynamics during maternal to zygotic transition. Genome Res, 21, 13281338. doi: $10.1101 /$ gr.116012.110.

Alarcon, J.A., \& Alvarez, M.C. (1999). Genetic identification Sparidae species by isozyme markers. Applications to interspecific hybrids. Aquaculture, 173, 95-103.

Alarcon, J.A., Magoulas, A., Georgakopoulos, T., Zouros, E., \& Alvarez, M.C. (2004). Genetic comparison of wild and cultivated European populations of the Gilthead Sea bream (Sparus aurata). Aquaculture, 230, 65-80. doi: 10.1016/S0044-8486(03)00434-4

Allendorf, F., Ryman, N., \& Utter, F. (1987). Genetics and fishery management: Past, present and future. In: N. Ryman and F.M. Utter (Eds.), Population Genetics and Fishery Management, Washington: University of Washington: 1-20.

Althoff, D.M., Gitzendanner, M.A., \& Segraves, K.A. (2007). The utility of amplified fragment length polymorphisms in phylogenetics: a comparison of homology within and between genomes. Syst Biol, 56, 477-484. doi: 10.1080/10635150701427077

Amores, A., Catchen, J., Ferrara, A., Fonttenot, Q., \& 
Postllethwait, J.H. (2011). Genome Evolution and Meiotic Maps by Massively Parallel DNA Sequencing: Spotted Gar, an Outgroup for the Teleost Genome Duplication. Genetics, 188, 799-808. doi: 10.1534/genetics.111.127324.

Arcand, S.L., Mes-Masson, A.M., \& Provencher, D. (2004). Gene expression microarray analysis and genome databases facilitate the characterization of a chromosome 22 derived homogeneously staining region. Mol Carcinog, 41, 17-38. doi: $10.1002 / \mathrm{mc} .20038$

Arnold, M.L., \& Martin, N.H. (2009). Adaptation by introgression. J Biol, 8:82. doi:10.1186/jbiol176

Avise, J.C., Helfman, G.S., Saunders, N.C., \& Hales, H.S. (1986). Mitochondrial DNA differentiation in North Atlantic eels: population genetic consequences of an unusual life history pattern. Proc Natl Acad Sci, 83, 4350-4354. doi: 10.1098/rspb.2002.2301

Bagley, M.J., Anderson, S.L., \& May, B. (2001). Choice of methodology for assessing genetic impacts of environmental stressors: polymorphism and reproducibility of RAPD and AFLP fingerprints. Ecotox, 10, 239-244. doi: 10.1023/A:1016625612603

Bardakci, F. (2001). Random amplified polymorphic DNA (RAPD) markers. Turk J Biol, 25, 185-196.

Bardakci, F., \& Skibinski, D.O.F. (1994). Application of the RAPD technique in tilapia fish: species and subspecies identification. Heredity, 73, 117-123. doi: 10.1038/hdy.1994.110

Benzie, J.A., Ballment, E., Forbes, A.T., Demetriades, N.T., Sugama, K., Haryanti., \& Moris, S. (2002). Mitochondrial DNA variation in Indo- Pacific populations of the giant tiger prawn, Penaeus monodon. Mol Ecol, 11, 2553- 2569. doi: 10.1046/j.1365-294X.2002.01638.x

Bernardo, R. (2008). Molecular markers and selection for complex traits in plants: learning from the last 20 years. Crop Sci, 48, 1649-1664. doi: 10.2135/cropsci2008.03.0131

Billington, N., \& Hebert, P.D.N. (1991). Mitochondrial DNA diversity in fishes and its implications for introductions. Can. J Fish Aqua Sci, 48, 80-94.

Birky, C.W., Fuerst, P., \& Maruyama, T. (1989). Organelle gene diversity under migration, mutation, and drift: equilibrium expectations, approach to equilibrium, effects of heteroplasmic cells, and comparison to nuclear genes. Genet, 121, 613-627.

Blears, M.J., De-Grandis, S.A., Lee, H., \& Trevors, J.T. (1998). Amplified fragment length polymorphism (AFLP): review of the procedure and its applications. $J$ Ind Microbiol Biotechnol, 21, 99-114.

Boore JL. (1999). Animal mitochondrial genomes. Nucleic Acids Res, 27, 1767-1780.

Bondari, K. (1984). Reproductive performance, growth, and survival of selected and wild selected channel catfish. Theor Appl Genet, 68, 391-395.

Botstein, D., White, R.L., Skolnick, M., \& Davis, R.W. (1980). Construction of a genetic linkage map in man using restriction fragment length polymorphisms. Am J Hum Genet, 32, 314- 331.

Caetano-Anolle's, G., \& Bassam, B.J. (1993). DNA Amplification fingerprinting using arbitrary oligonucleotide primers. App Biochem Biotechnol, 42, 189-200.

Campbell, D., Duchesne, P., \& Bernatchez, L. (2003). AFLP utility for population assignment studies: analytical investigation and empirical comparison with microsatellites. Mol Ecol, 12, 1979-1991. doi: 10.1046/j.1365-294X.2003.01856.x

Carleton, K.L., Streelman, J.T., Lee, B.Y., Garnhart, N., Kidd, M., \& Kocher, T.D. (2002). Rapid isolation of CA microsatellites from the tilapia genome. Anim Genet, 33, 140-144. doi: 10.1046/j.13652052.2002.00817.x

Carvalho, G.R., \& Hauser, L. (1995). In: Molecular genetics and the stock concept in fisheries. Molecular Genetics in Fisheries, London: Chapman and Hall: 55-80.

Chan, K.M.A., \& Levin, S.A. (2005). Leaky prezygotic isolation and porous genomes: rapid introgression of maternally inherited DNA. Evol, 59, 720-729. doi: 10.1554/04-534

Chapman, R.W., Patton, J.C., \& Eleby, B. (1994). Comparisons of mitochondrial DNA variation in four alosid species as revealed by the total genome, the NADH dehydrogenase $\mathrm{I}$ and the cytochrome $\mathrm{b}$ regions. In: Genetics and evolution of aquatic organisms, Edited by A.R. Beaumont. Chapman \& Hall, London, pp. 249-262.

Charlesworth, B., \& Charlesworth, D. (2016). Population genetics from 1966 to 2016. Heredity. doi:10.1038/hdy.2016.55

Chow, S., Clarke, M.E., \& Walse, P.J. (1993). PCR-RFLP analysis on thirteen western Atlantic snappers (subfamily Lutjaninae): a simple method for species and stock identification. Fish Bull, 91, 619-627.

Chow, S., \& Kishino, H. (1995). Phylogenetic relationships between tuna species of genus Thunnus (Scombridae: Teleostei): Inconsistent implications from morphology, nuclear and mitochondrial genomes. $J$ Mol Evol, 41, 741-748. doi: 10.1007/BF00173154

Cnaani, A., Ron, M., Lee, B.Y., Hulata, G., Kocher, T.D., \& Seroussi, E. (2002). Mapping the transferrin gene in tilapia. Anim Genet, 33, 78- 80.

Cohen, R., Chalifa-Caspi, V., Williams, T.D., Auslander, M., George, S.G., Chipman, J.K., \& Tom, M. (2008). Estimating the efficiency of fish cross species cDNA microarray hybridization. Mar Biotechnol, 9, 491499. doi:10.1007/s10126-007-9078-1

Coppe, A., Pujolar, J.M., Maes, G.E., Larsen, P.F., Hansen, M.M., Bernatchez, L., Zane, L., \& Bortoluzzi, S. (2010). Sequencing, de novo annotation and analysis of the first Anguilla anguilla transcriptome: EeelBase opens new perspectives for the study of the critically endangered European Eel. BMC Genome, 11:635 doi: 10.1186/1471-2164-11-635

Cossins, A.R., \& Crawford, D.L. (2005). Fish as models for environmental genomics. Nat Rev Genet, 6, 324-333. doi: $10.1038 / \operatorname{nrg} 1590$

Crawford, J.E., Guelbeogo, W.M., Sanou, A., Traore, A., Vernick, K.D., Sagnon, N., \& Lazzaro, B.P. (2010). De novo transcriptome sequencingin Anopheles funestus using Illumina RNA-seq technology. PLoS ONE, 5:14202. doi: 10.1371/journal.pone.0014202.

Crollius, H.R., \& Weissenbach, J. (2005). Fish genomics and biology. Genome Res, 15, 1675-1682. doi: 10.1101/gr.3735805

Cronin, M.A., Spearman, W.J., \& Wilmot, R.L. (1993). Mitochondrial DNA variation in chinook (Oncorhynchus tshawytscha) and chun salmon (O. keta) detected by restriction enzyme analysis of polymerase chain reaction (PCR) products. Can $J$ Fish Aquat Sci, 50, 708-715. doi: 10.1139/f00-200

Crossland, S., Coates, D., Grahame, J., \& Mill, P.J. (1993). 
Use of random amplified polymorphic DNAs (RAPDs) in separating two sibling species of Littorina. Mar Ecol Prog Ser, 96, 301- 305.

Dan, C., Mei, J., Wang, D., \& Gui, J. F. (2013). Genetic differentiation and efficient sex-specific marker development of a pair of $\mathrm{Y}$-and $\mathrm{X}$-linked markers in yellow catfish. Int J Biol Sci, 9(10), 1043-1049. doi:10.7150/ijbs.7203

Davey, J.W., Hohenlohe, P.A., Etter, P.D., Boone, J.Q., Catchen, J.M., \& Blaxter, M.L. (2011). Genome-wide genetic marker discovery and genotyping using next generation sequencing. Nat Rev Genet, 12, 499-510. doi: $10.1038 / \mathrm{nrg} 3012$.

Devlin, R.H., McNeil, B.K., Groves, T.D.D., \& Donaldson, E.M. (1991). Isolation of a Y chromosomal DNA probe capalable for determining genetic sex in chinook salmon (Oncorhynchus tshawytscha). Can $J$ Fish Aquat Sci, 48, 1606-1612.

Dodgson, J.B., Cheng, H.H., \& Okimoto, R. (1997). DNA marker technology: a revolution in animal genetics. Poult Sci, 76, 1108-1114. doi: 10.1093/ps/76.8.1108

Dunham, R.A., \& Smitherman, R.O. (1983). Response to selection and realized heritability for body weight in three strains of channel catfish, Ictalurus punctatus, grown in earthen ponds. Aquaculture, 33, 88-96.

Ewart, K.V., Belanger, J.C., Williams, J., Karakach, T., Penny, S., Stephen, C.M., Tsoi, S.C.M., Richards, R.C., \& Douglas, S.E. (2005). Identification of genes differentially expressed in Atlantic salmon (Salmo salar) in response to infection by Aeromonas salmonicida using cDNA microarray technology. Dev Comp Immunol, 29, 333-347. doi:10.1016/j.dci.2004.08.004

Fast, M.D., Muise, D.M., Easy, R.E., Ross, N.W., \& Johnson, S.C. (2006). The effects of Lepeophthirius salmonis infection on the stress response and immunological status of Atlantic salmon (Salmo salar). Fish Shellfish Immunol, 21, 228-241doi: 10.1016/j.fsi.2005.11.010

Ferguson, M. (1994). The role of molecular genetic markers in the management of cultured fishes. Reviews in Fish Biology and Fisheries, 4(3), 351-373. https://doi.org/10.1007/BF00042909

Funk, D.J., \& Omland, K.E. (2003). Species-level paraphyly and polyphyly: frequency,causes, and consequences, with insights from animal mitochondrial DNA. Annu Rev Ecol Evol Syst, 34, 397-423. 10.1146/annurev.ecolsys.34.011802.132421

Giuffra, E., Bernatchez, L., \& Guyomard, R. (1994). Mitochondrial control region and protein coding genes sequence variation among phenotypic forms of brown trout, Salmo trutta L., from northern Italy. Mol Ecol, 3, 161-171. doi: 10.1111/j.1365294X.1994.tb00117.x

Gjedrem, T., \& Baranski, M. (2009).In: Selective Breeding in Aquaculture: An Introduction. Springer, New York.

Gold, J.R., Richardson, L.R., Furman, C., \& King, T.L. (1993a). Mitochondrial DNA differentiation and population structure in red drum (Sciaenops ocellatus) from the Gulf of Mexico and Atlantic Ocean. Mar Biol, 116, 175-185. doi: 10.1007/BF00350007

Gonzalez, S.F., Krug, M. J., Nielsen, M.E., Santos, Y., \& Call, D.R. (2004). Simultaneous detection of marine fish pathogens by using multiplex PCR and a DNA microarray. J Clin Microbiol, 42, 1414- 1419. doi: 10.1128/JCM.42.4.1414-1419.2004
Graslund, S., \& Bengtsson, B.E. (2001). Chemicals and biological products used in southeast Asian shrimp farming, and their potential impact on the environment-a review. Sci of the Total Environment, 280, 93-131. doi:10.1016/S0048-9697(01)00818-X

Graves, J.E., McDowell. J.R., \& Jones, M.L. (1992). A genetic analysis of weakfish Cynoscion regalis stock structure along the mid-Atlantic coast. Fish Bull, 90: 469-475.

Groenen, M.A., Cheng, H.H., Bumstead, N., Benkel, B.F., Briles, W.E., Burke, T., Burt, D.W., Crittenden, L.B., Dodgson, J., Hilei, J., Lamont, S., Leon, A.P., Soller, M., Takahashi, H., \& Vignal, A. (2000). A consensus linkage map of the chicken genome. Genome Res, 10, 137-147. doi: 10.1101/gr.10.1.137

Gupta, P.K., \& Rustgi, S. (2004). Molecular markers from the transcribed/expressed region of the genome in higher plants. Funct Integr Genomics, 4, 139-162. doi: 10.1007/s10142-004-0107-0

Hadrys, H., Balick, M., \& Schierwater, B. (1992). Applications of random amplified polymorphic DNA (RAPD) in molecular ecology. Mol Ecol, 1, 55-63. doi: 10.1111/j.1365-294X.1992.tb00155.x

Hallerman, E.M., Dunham, R.A., \& Smitherman, R. O. (1986). Selection or drift isozyme allele frequency changes among channel catfish selected for rapid growth. Trans Am Fish Soc, 115, 60-68.

He, C., Chen, L., Simmons, M., Li, P., Kim, S., \& Liu, Z.J. (2003b). Putative SNP discovery in interspecific hybrids of catfish by comparative EST analysis. Anim Genet, 34, 445-448. doi: 10.1046/j.02689146.2003.01054.x

Hegedus, Z., Zakrzewska, A., Agoston, V.C., Ordas, A., Racz, P., Mink, M., Spanik, H.P., \& Meijer, A.H. (2009). Deep sequencing of the zebrafish transcriptome response to mycobacterium infection. Mol Immunol, 46, 2918-2930. doi: 10.1016/j.molimm.2009.07.002.

Heist, E.J., \& Gold, J.R. (1999). Microsatellite DNA variation in sandbar sharks (Carcharhinus plumbeus) from the Gulf of Mexico and mid-Atlantic bight. Copeia, 1, 182-186

Hirschfeld, D., Dhar, A.K., Rask, K., \& Alcivar-Warren, A. (1999). Genetic diversity in the eastern oyster (Crassostrea virginica) from Massachusetts using RAPD technique. J Shellfish Res, 18, 121- 125.

Hoshino, A.A., Bravo, J.P., Nobile, P.M., Morelli, K.A., \& Karina. (2012). Microsatellite as Tools for Genetic Diversity Analysis. In: Environmental Science "Genetics Diversity in Microrganism". Caliskan M (Eds). ISBN 978-953-51-00064-5, CC BY 3.0 license.

Hubert, N., Meyer, C.P., Bruggemann, H.J., Guerin, F., Komeno, R.J.L., Espiau, B., Causse, R., Williams, J.T., \& Planes, S. (2012). Cryptic diversity in IndoPacific coral reef fishes revealed by DNA-barcoding provides new support to the centre of overlap hypothesis. PLos ONE 7(3): e28987.

Houston, R. D., Davey, J. W., Bishop, S. C., Lowe, N. R., Mota-Velasco, J. C., Hamilton, A., \& Gharbi, K. (2012). Characterisation of QTL-linked and genomewide restriction site-associated DNA (RAD) markers in farmed Atlantic salmon. BMC genomics, 13(1), 244.

Johansen, S.D., Karlsen, B.O., Furmanek, T., Andreassen, M., Jorgensen, T.E., Bizuavehu, T.T., Breines, R., Emblem, A., Kettunen, P., Luukko, K., Edvardsen, R.B., Nordeide, J.T., Coucheron, D.H., \& Moum. 
(2011). RNA deep sequencing of the Atlantic cod transcriptome. Com Biochem Physiol Part D: 18-22. doi:10.1016/j.cbd.2010.04.005

Joshi, R., Venkatesh, K., \& Srinivas. R. (2004). Genetic dissection of itpr gene function reveals a vital requirement in aminergic cells of Drosophila larvae. Genet, 166, 225-236. doi:10.1534/genetics.166.1.225

Ju, Z., Wells, M.C., Heater, S.J., \& Walter, R.B. (2007). Multiple tissue gene expression analyses in Japanese medaka (Oryzias latipes) exposed to hypoxia. Comp Biochem Physiol C Toxicol Pharmacol, 145, 134-144. doi: 10.1016/j.cbpc.2006.06.012

Khan, S.A., Hussain, D., Askari, E., Stewart, J.M.D., Malik, K.A., \& Zafar, Y. (2000). Molecular phylogeny of Gossypium species by DNA fingerprinting. Theor Appl Genet, 101, 931-938. doi: $10.1007 / \mathrm{s} 001220051564$

Kim, J.S., Ahn, S.G., Kim, C.K., \& Shim, C.K. (2010). Screening of rice blast resistance genes from aromatic rice germplasms with SNP markers. Plant Pathol J, 26, 70-79. doi: 10.5423/PPJ.2010.26.1.070

Klinbunga, S., Ampayup, P., Tassanakajon, A., Jarayabhand, P., \& Yoosukh, W. (2000). Development of species specific markers of the tropical oyster (Crassostrea belcheri) in Thailand. Mar Biotechnol, 2, 476- 484. doi: 10.1007/s101260000028

Kocher, T.D., Thomas, W.K., Meyer, A., Edwards, S.V., Paabo, S., Vilablanca, F.X., \& Wilson, A.C. 1989. Dynamics of mitochondrial DNA evolution in animals: amplification and sequencing with conserved primers. Proc Nat Acad Sci USA, 86, 6196-6200

Koskinen, H., Pehkonen, P., Vehniainen, E., Krasnov, A., Rexroad, C., Afanasyev, S., Molsa, H., \& Oikari, A. (2004). Response of rainbow trout transcriptome to model chemical contaminants. Biochem Biophys Res Comm, 320, 745- 53. DOI: 10.1016/j.bbrc.2004.06.024

Kumar, L.S. (1999). DNA markers in plant improvement: An overview. Biotechnol Adv, 17: 143-182. doi:10.1016/S0734-9750(98)00018-4

Kurath, G. (2005). Overview of recent DNA vaccine development for fish. Developmental Biol, 121, 201213.

Le Bras, Y., Dechamp, N., Krieg, F., Filangi, O., Guyomard, R., Boussaha, M., Bovenhuis, H., Pottinger, T.G., Prunet, P., Roy, P., \& Quille, E. (2011). Detection of QTL with effects on osmoregulation capacities in the rainbow trout (Oncorhynchus mykiss). BMC Genet, 12, 46. doi: 10.1186/1471-2156-12-46

Lewis, J.M., Hori, T.S., Rise, M.L., Walsh, P.J., \& Currie, S. (2010). Transcriptome responses to heat stress in the nucleated red blood cells of the rainbow trout (Oncorhynchus mykiss). Physiol Genomics, 42, 361373. doi: 10.1152/physiolgenomics.00067.2010

Li, L. , \& Guo, X. (2004). AFLP-based genetic linkage maps of the pacific oyster Crassostrea gigas Thunberg Mar Biotechnol, 6, 26-36. doi: 10.1007/s10126-0030001-0

Lindenstrom, T., Sigh, J., Dalgaard, M.B., \& Buchmann, K. (2006). Skin expression of IL $1 \beta$ in East Atlantic salmon, Salmo salar L., highly susceptible to Gyrodactylus salaris infections is enhanced compared to a low susceptibility Baltic stock. J Fish Dis, 29, 123-128. doi: 10.1111/j.1365-2761.2006.00696.x

Liu, Z.J., Li, P., Kucuktas, H., Nichols, A., Tan, G., Zheng, X., Argue, B.J., Yant, R., \& Dunham, R.A. (1999c). Development of AFLP markers for genetic linkage mapping analysis using channel catfish and blue catfish interspecific hybrids. Trans. Am Fish Soc, $128, \quad 317-327$. doi: $10.1577 / 1548$ 8659(1999)128<0317:DOAFLP>2.0.CO;2

Liu, S., Zhang, Y., Zhou, Z., Waldbieser, G., Sun, F., Lu, J., Zhang, J., Jiang, Y., Zhang, H., Wang, X., Rajendran, K.V., Khoo, L., Kucuktas, H., Peatman, E., \& Liu, Z. (2013). Efficient assembly and annotation of the transcriptome of catfish by RNA-Seq analysis of a doubled haploid homozygote. BMC Genomics, 14:1. doi: 10.1186/1471-2164-13-595

Liu, Z., Karsi, A., Li, P., Cao, D., \& Dunham, R.E. (2003). An AFLP-based genetic linkage map of channel catfish (Ictalurus punctatus) constructed by using an interspecific hybrid resource family. Genet, 165, 687694.

Liu, Z. (2006). Genomic variations and Marker technologies for Genome-based selection In: Next generation sequencing and whole genome selection (eds), Zhanjiang v, Wiley- Black Well Publishers.

Liu, Z.J. (2011). Next Generation Sequencing and Whole Genome Selection in Aquaculture. Wiley-Blackwell, New York.

Liu, Z.J., \& Cordes, J.F. (2004). DNA marker technologies and their applications in aquaculture genetics. Aquaculture, 238, 1-37. doi:10.1016/j.aquaculture.2004.05.027

Liu, Z.J., Li, P., \& Argue, B.J. (1999b). Random amplified polymorphic DNA markers: usefulness for gene mapping and analysis of genetic variation of catfish. Aquaculture, 174, 59- 68. doi: 10.1016/S00448486(99)00007-1

Liu, Z.J., Li, P., Kucuktas, H., Nichols, A., Tan, G., Zheng, X., Argue, B.J., Yant, R., \& Dunham, R.A. (1999c). Development of AFLP markers for genetic linkage mapping analysis using channel catfish and blue catfish interspecific hybrids. Trans Am Fish Soc, 128, 317 - $327 . \quad$ doi:10.1577/15488659(1999)128<0317:DOAFLP>2.0.CO;2

Liu, Z.J., Li, P., Argue, B., \& Dunham, R. (1998a). Inheritance of RAPD markers in channel catfish (Ictalurus punctatus), blue catfish (I. furcatus) and their F1, F2 and backcross hybrids. Anim Genet, 29, 58-62. doi: 10.1046/j.1365-2052.1998.00284.x

Liu, Z.J., Nichols, A., Li, P., \& Dunham, R. (1998b). Inheritance and usefulness of AFLP markers in channel catfish (Ictalurus punctatus), blue catfish (I. furcatus) and their F1, F2 and backcross hybrids. Mol Gen Genet, 258, 260 - 268. doi: 10.1007/s004380050730

Lorenzen, N., Lorenzen, E., Einer-Jensen, K., \& Lapatra, S.E. (2002). DNA vaccines as a tool for analysing the protective immune response against rhabdoviruses in rainbow trout. Fish and Shellfish Immunol, 12, 439453. doi:10.1006/fsim.2002.0422

Majeed, A.A., Ahmed, N., \& Rao, K.R. (2004). AmpliBASE MT: a Mycobacterium tuberculosis diversity knowledgebase. Bioinfo, 20, 989-992. doi: 10.1093/bioinformatics/bth051

Maldini, M., Marzano, F.N., Fortes, G.G., Papa, R., \& Gandolfi, G. (2006). Fish and seafood traceability based on AFLP markers: Elaboration of a species database. Aquaculture, 261, 487-494. doi: 10.1016/j.aquaculture.2006.07.010

Mallet, J. (2005). Hybridization as an invasion of the genome. Trends Ecol Evol, 20, 229-237. 
Marsjan, P.A., \& Oldenbroek, J.K. (2007). Molecular markers, a tool for exploring genetic diversity. In: The state of the world's animal genetic recourses for food and Agriculture- Rome: FAO, Scientific book, Section C, Part 4, 359 - 379.

Martin, S.A., Blaney, S.C., Houlihan, D.F., \& Secombes, C.J. (2006). Transcriptome response following administration of a live bacterial vaccine in Atlantic salmon (Salmo salar). Mol Immunol, 43, 2089-2106. doi:10.1016/j.molimm.2005.10.007

McCouch, S., Zhao, K., Wright, M., Tung, K., Ebana, M., Thomsom, A., Reynolds, D., Wang, G.D., \& Ali, L. (2010). Development of genome-wide SNP assays for rice. Breed $\quad S c i, \quad 60, \quad 524-535$. doi:10.1270/jsbbs.60.524

Metzker, M.L. (2010). Sequencing technologies -the next generation. Nature Rev Genet, 11, 31-46. doi: $10.1038 / \mathrm{nrg} 2626$.

Meyer, A. (1994). Molecular phylogenetics studies of fish. In: Genetics and evolution of aquatic organisms, Beaumont AR (Eds), Chapman \& Hall, London, 219238.

Miller, M.R., Dunham, J.P., Amores, A., Cresko, W.A., \& Johnson, E.A. (2007). Rapid and cost-effective polymorphism identification and genotyping using restriction site associated DNA (RAD) markers. Genome Res, 17, 240-248. doi: 10.1101/gr.5681207

Moore, S.S., Whan, V., Davis, G.P., Byrne, K., \& Hetzei, D.J.S. (1999). The development and application of genetic markers for the Kuruma prawn Penaeus japonicus. Aquaculture, 173, 19-32. doi: 10.1016/S0044-8486(98)00461-X

Moose, S.P., \& Mumm, R.H. (2008). Molecular plant breeding as the foundation for 21st century crop improvement. Plant Physiol, 147, 969-977. doi: http:/ /dx.doi.org/10.1104/pp.108.118232

Morin, P.A., Luikart, G., \& Wayne, R.K. (2004).The SNP working group, SNPs in ecology, evolution and conservation. Trends Ecol Evol, 19, 208-216. doi: 10.1016/j.tree.2004.01.009

Mudasir, H., Sawant M. S., Pawar R. A., Pawsae A. S., Bhat F. A., (2016). Stock identification of Nemipterus japonicus along west coast of India using RAPD markers, SKUAST Journal of Research, 18(2), 130137.

Naish K.A., \& Hard, J.J. (2008). Bridging the gap between the genotype and the phenotype: linking genetic, variation, selection and adaptation in fishes. Fish and Fisheries, 9: 396-422. doi: 10.1111/j.14672979.2008.00302.x

Naish, K.A., \& Park, L.K. (2002). Linkage relationships for 35 new microsatellite loci in chinook salmon Oncorhynchus tshawytscha. Anim Genet, 33, 218-316. doi: 10.1046/j.1365-2052.2002.t01-4-00886.x

Nevado, B., Koblmüller, S., Sturmbauer, C., Snoeks, J., Usano, J., \& Verheyen, E. (2009). Complete mitochondrial DNA replacement in a Lake Tanganyika cichlid fish. Mol Ecol, 18, 4250-4255. doi: 10.1111/j.1365-294X.2009.04348.x

Nichols, K.M., Young, W.P., \& Danzmann, R.G. (2003). A consolidated linkage map for rainbow trout (Oncorhynchus mykiss). Anim Genet, 34, 102-115. doi: 10.1046/j.1365-2052.2003.00957.x

Nijman, I.J., Otsen, M., Verkaar, E.L., Ruijter, C., Hanekamp, E., Ochieng, J.W., Shamshad, S., Rege, J.E.O., Hanotte, O., Barwegen, W., Sulawati, T., \& Lenstra, J.A. (2003). Hybridization of banteng (Bos javanicus) and zebu (Bos indicus) revealed by mitochondrial DNA, satellite DNA, AFLP and microsatellites. Heredity, 90, 10-16. doi:10.1038/sj.hdy.6800174.

Norman, J.A., Moritz, C., \& Limpus, C.J. (1994), Mitochondrial DNA control region polymorphisms: genetic markers for ecological studies for marine turtles. Mol Ecol, 3, 363-373. doi: 10.1111/j.1365294X.1994.tb00076.x

Norris, A.T., Bradley, D.G., \& Cunningham, E.P. (1999), Microsatellite genetic variation between and within farmed and wild Atlantic salmon (Salmo salar) populations. Aquaculture 180, 247-264.

Okumus, I., \& Ciftci, Y. (2003), Fish Population Genetics and Molecular Markers: II- Molecular Markers and Their Applications in Fisheries and Aquaculture. Turkish J Fisheries and Aquatic Sci, 3, 51-79.

Ordas, A., Hegedus, Z., \& Henkel, C.V. (2011), Deep sequencing of the innate immune transcriptomic response of zebrafish embryos to Salmonella infection. Fish shellfish Immunol, 5, 716-24. doi: 10.1016/j.fsi.2010.08.022

Ovenden, J. R., Berry, O., Welch, D. J., Buckworth, R. C., \& Dichmont, C. M. (2015). Ocean's eleven: a critical evaluation of the role of population, evolutionary and molecular genetics in the management of wild fisheries. Fish and Fisheries, 16(1), 125-159. doi: 10.1111/faf.12052.

Padi, J.N. (1995), Response and correlated responses to four generations of selection for increased body weight in the Kansas strain channel catfish, Ictalurus punctatus, grown in earthen ponds. M.S. Thesis: Auburn University.

Palma, J., Alarcon, J.A., Alvarez, C., Zouros, E., Magoulas, A., \& Andrade, J.P. (2001), Developmental stability and genetic heterozygosity in wild and cultured stocks of gilthead sea bream. J Marine Biol Assoc UK, 812, 283-288. doi: 10.1017/S0025315401003757

Palti, Y., Parsons, J.E., \& Thorgaard, G.H. (1999), Identification of candidate DNA markers associated with IHN virus resistance in backcrosses of rainbow (Oncorhynchus mykiss) and cutthroat trout (O. clarki). Aquaculture, 173, 81-94. doi:10.1016/S00448486(98)00471-2

Palti, Y., Shirak, A., Cnaani, A., Feldmesser, E., Avtalion, R.R., Hulata, G., \& Ron, M. (2001), A microsatellite locus has more than one copy in the genome of two tilapia species (Oreochromis aureus and O. niloticus). Anim Genet, 32, 40-41. doi: 10.1046/j.13652052.2001.0647a.x

Panicker, G., Call, D.R., \& Krug, M.J. (2004), Detection of pathogenic Vibrio spp. in shellfish by using multiplex PCR and DNA microarrays. Applied and Environmental Microbiol, 70, 7436-7444. doi: 10.1128/AEM.70.12.7436-7444.2004

Perkins, D.L., \& Krueger, C.C. (1993), Heritage brook trout in northeastern USA: Genetic variability within and among populations. Transaction of American Fisheries Society, 122, 1515-1532.

Quinteiro, J., Sotelo, C.G., Rehbein, H., Pryde S.E., Edina, I., Perez-Martin, R.I., Rey-Mendez, M., \& Mackie, I.M. (1998), Use of mtDNA direct polymerase chain reaction (PCR) sequencing and PCR-restriction fragment length polymorphism methodologies in species identification of canned tuna. J Agric Food Chem, 46, 1662-1669. doi: 10.1021/jf970552.

Rasal, K. D., Chakrapani, V., Pandey, A. K., Rasal, A. R., 
Sundaray, J. K., Ninawe, A., \& Jayasankar, P. (2017). Status and future perspectives of single nucleotide polymorphisms (SNPs) markers in farmed fishes: Way ahead using next generation sequencing. Gene Reports, 6, 81-86. doi: 10.1016/j.genrep.2016.12.004

Rasmussen, R.S., Morrissey, M.T., \& Hebert, P.D.N. (2009), DNA barcoding of response and immunological status of Atlantic salmon (Salmo salar). Fish Shellfish Immunol, 21, 228- 241.

Renn, S.C., Aubin-Horth, N., \& Hofmann, H.A. (2004), Biologically meaningful expression profiling across species using heterologous hybridization to a cDNA microarray. BMC Genomics, 51, 42. doi:10.1186/1471-2164-5-42

Richard, I., \& Beckman, J.S. (1995), How neutral are synonymous codon mutations? Nat Genet, 10, 259. doi:10.1038/ng0795-259

Rise, M.L., VonSchalburg, K.R., Brown, G.D., Mawer, M.A., Devlin, R.H., Kuipers, N., Busby, M., BeetzSargent, M., Alberto, R., Gibbs, R., Hunt, P., Shukin, R., Zeznik, J.A., Nelson, C., Jones, S.R.M., Smailus, D.E., Jones, S.J.M., Schein, J.E., Marra, M.A., Butterfield, Y.S.N., Stott, J.M., Siemon, H.S., Davidson, W.S., \& Koop, (2004), Development and application of a salmonid EST database and cDNA microarray: data mining and interspecific hybridization characteristics. Genome Res, 14, 478490. doi: $10.1101 /$ gr. 1687304

Russell, V.J., Hold, G.L., Pryde, S.E., Rehbein, H., Quinterio, J., Rey- Mendez, M., Sotelo, C.G., PerezMartin., Santos, A.T., \& Rosa, C. (2000), Use of restriction fragment length polymorphism to distinguish between salmon species. J Agric Food Chem, 48, 2184-2188. doi: 10.1021/jf991213e.

Saiki, R.K., Scharf, S., Faloona, F., Mullis, K.B., Horn, K.B., Horn, G.T, Erlich, H.A., \& Arnheim, N. (1985), Enzymatic amplification of $\mathrm{B}$-globin genomic sequences and restriction site analysis for diagnosis of sickle cell anemia. Sci, 230, 1350-1354. doi: 10.1126/science. 2999980

Sakamoto, T., Danzmann, R.G., Gharbi, K., Howard, P., Ozaki, A., Khoo, S.K., Woram, R.A., Okamoto, N., Ferguson, M.M., Holm, L.E., Guyomard, R., \& Hoyheim, B. (2000), A microsatellite linkage map of rainbow trout (Oncorhynchus mykiss) characterized by large sex-specific differences in recombination rates. Genet, 155, 1331-1345.

Salem, M., Vallejo, R.L., Leeds, T.D., Palti, Y., Liu, S., Sabbagh, A., Rexroad, C.E., \& Yao, J. (2012), RNASeq Identifies SNP Markers for Growth Traits in Rainbow Trout. Plos ONE, 7, 1-13. doi:10.1371/journal.pone.0036264.

Salem, M., Kenney, P.B., Rexroad, C.E., \& Yao, J. (2006), Microarray gene expression analysis in atrophying rainbow trout muscle: a unique non mammalian muscle degradation model. Physiol Genomics, 281, 33-45. doi: 10.1152/physiolgenomics.00114.2006.

Salem, M., Rexroad, C.E., Wang, J., Thorgaard, G.H., \& Yao, J. (2010), Characterization of the rainbow trout transcriptome using Sanger and 454-pyrosequencing approaches. BMC Genomics, 11, 564. doi: 10.1186/1471-2164-11-564.

Sharma, S.K., Dawson, I.K., \& Waugh, R. (1995), Relationship among cultivated and wild lentils revealed by RAPD analysis. Theor Appl Genet, 85, 697-701. doi: 10.1007/BF00223292.

Sigh, J., Lindenstrom, T., \& Buchmann, K. (2004),
Expression of pro-inflammatory cytokines in rainbow trout (Oncorhynchus mykiss) during an infection with Ichthyophthirius multifiliis. Fish Shellfish Immunol, 17, 75-86. doi:10.1016/j.fsi.2003.12.005.

Spies, I.B., Gaichas, S., Stevenson, D.E., Orr, J.W., \& Canio, M.F. (2006), DNA-based marker-assisted selection in crop plants. Mol Breed, 3, 87-103.

Stallen van, N., Noten, V., Demeulemeester, M., \& De Proft, M. (2000), Identification of commercial chicory cultivars for hydroponic forcing and their phenetic relationships revealed by random amplified polymorphic DNAs and amplified fragment length polymorphisms. Plant Breed, 119, 265-270. doI: 10.1046/j.1439-0523.2000.00499.x

Steele, C.A,. Wheeler, P.A., \& Thorgaard, G.H. (2008), Mitochondrial And Maternal Effects On Growth In Clonal Rainbow, Abstract of Plant \& Animal Genome Conference XVI.

Streelman, J.T., \& Kocher, T.D. 2002. Microsatellite variation associated with prolactin expression and growth of salt-challenged tilapia. Physiol Genomics, 9: 1-4. doi: 10.1152/physiolgenomics.00105.2001.

Sunyaev, S., Hanke, J., Aydin, A., Wirkner, U., Zastrow, I., Reich, J., \& Bork, P. (1999), Prediction of nonsynonymous single nucleotide polymorphisms in human disease-associated genes. J Mol Med, 77, 754760. doi:10.1007/s001099900059.

Surget-Groba, Y., \& Montoya-Burgos, J.I. (2010), Optimization of de novo transcriptome assembly from next-generation sequencing data. Genome Res, 14321440. doi: 10.1101/gr.103846.109.

Tan, G., Karsi, A., Li, P., Kim, S., Zheng, X., Kucuktas, H., Argue, B.J., Dunham, R.A., \& Liu, Z.J. (1999), Polymorphic microsatellite markers in Ictalurus punctatus and related catfish species. Mol Ecol, 8, 1758-1760. doi: 10.1046/j.1365-294x.1999.00723-3.x

Tanck, M.W., Palstra, A.P., \& Van der Weerd, (2001), Segregation of microsatellite alleles and residual heterozygosity at single loci in homozygous androgenetic common carp (Cyprinus carpio L.). Genome, 44, 743-751. doi:10.1139/g01-072

Tassanakajon, A., Pongsomboon, S., \& Jarayabhand, P. (1998), Genetic structure in wild populations of black tiger shrimp (Penaeus monodon) using randomly amplified polymorphic DNA analysis. $J$ Mar Biotechnol, 6, 249-254.

Tautz, D. (1989), Hypervariability of simple sequences as a general source for polymorphic DNA markers. Nucl Acids Res, 17, 6463- 6471. doi: 10.1093/nar/17.16.6463

Tilton, S.C., Givan, S.A., Pereira, C.B., Bailey, G.S., \& Williams, D.E. (2006), Toxicogenomic profiling of the hepatic tumor promoters indole-3-carbinol, $17 \beta$ estradiol and $\beta$ naphthoflavone in rainbow trout. Toxicol Sci, 90, 61-72. doi: 10.1093/toxsci/kfi341

Ton, C., Stamatiou, D., Dzau, V. J. (2002), Construction of a zebrafish cDNA microarray: gene expression profiling of the zebra fish during development. Biochem Biophys Res Commun, 296, 1134-1142. doi:10.1016/S0006-291X(02)02010-7

Van Oppen, M.J.H., Klerk, H., Olsen, J.L., \& Stam, W.T. (1996), Hidden diversity in marine algae: some examples of genetic variation below the species level. J Mar Biol Assoc U.K, 76, 239-242.

Vandeputte, M., Rossignol, M., \& Pincent, C. (2011). From theory to practice: Empirical evaluation of the assignment power of marker sets for pedigree analysis 
in fi sh breeding. Aquaculture, 314(1-4), 80-86. https://doi.org/10.1016/j.aquaculture.2011.01.043

Venkatesh, B., Hettwer, U., Koopmann, B., \& Karlovsky, P. (2005), Conversion of cDNA differential display results (DDRT-PCR) into quantitative transcription profiles. BMC Genomics, 6, 51. doi:10.1186/14712164-6-51.

Vithanage, V., \&Winks, C.W. (1992), Isozyme as genetic markers for Macadamia. Scientia Hort, 49, 103-115. doi:10.1016/0304-4238(92)90147-5

Vos, P., Hogers, R., Bleeker, M., Reijians, M., Lee, T., Hornes, M., Finters, A., Pot, J., Peleman, J., \& Kuiper, M. (1995), AFLP: a new technique for DNA fingerprinting. Nucleic Acids Res, 23, 4407-4414. doi: 10.1093/nar/23.21.4407

Waldbieser, G., Liu, Z.J., Wolters, W., \& Dunham, R.A. (1998), Review of progress in catfish gene mapping. Proceedings of the National Aquaculture Species Genome Mapping Workshop. Northeastern Regional Aquaculture Center, North Dartmouth, MA, Publication No. NRAC 98-001, pp. 31-38.

Wang, Z., Gerstein, M., \& Snyder, M. (2009), RNA-Seq: a revolutionary tool for transcriptomics. Nat Rev Genet, 101: 57-63. doi: $10.1038 / \mathrm{nrg} 2484$

Ward, R.D., \& Grewe, M. (1995), In: Appraisal of molecular genetic techniques in fisheries. G.R. Carvalho and T.J. Pitcher (Eds.), Molecular Genetics in Fisheries, London: Chapman \& Hall: 29-54.

Welsh, J., \& McClell, M. (1990), Fingerprinting genomes using PCR with arbitrary primers. Nucl Acids Res, 18, 7213-7218. doi: 10.1093/nar/18.24.7213

Williams, J.G., Kubelik, A.R., Livak, K.J., Rafalski, J.A., \& Tingey, S.V. (1990), DNA polymorphisms amplified by arbitrary primers are useful as genetic markers. Nucl Acids Res, 18, 6531- 6535.

Williamson, J.H. (2001), Broodstock management for imperilled and other fishes. In G. A. Wedemeyer, (Ed.). Fish hatchery management, second edition. American Fisheries Society, Bethesda, Maryland: 397-482.

Williamson, K.S., Cordes, J.F., \& May, B. (2001), Characterization of microsatellite loci in Chinook salmon (Oncorhynchus tshawytscha) and crossspecies amplification in other salmonids. Mol Ecol Notes, $\quad 2$, 17-19. doi: 10.1046/j.14718286.2002.00129.x

Wirgin, I.I., \& Waldam, J.R. 1994. What DNA can do for you. Fisheries, 19: 16-27.

Wolf, C., Hübner, P., \& Lüthy, J. (2000), Differentiation of sturgeon species by PCR-RFLP. Food Res Int, 32, 699-705. doi:10.1016/S0963-9969(99)00150-7

Wolfus, G.M., Garcia, D.K., \& Alcivar-Warren, A. (1997),
Application of the microsatellite techniques for analyzing genetic diversity in shrimp breeding programs. Aquaculture, 152, 35- 47.

Wolters, W.R., Johnson, M.R. (1994), Enteric septicemia resistance in blue catfish and three channel catfish strains. J Aquat Anim Health, 6, 329-334. doi: $10.1577 / 1548-$ 8667(1994)006<0329:ESRIBC>2.3.CO;2.

Wright, J.M. (1993), In: DNA fingerprinting in fishes. In: Hochachka, P.W., Mommsen, T. (Eds.), Biochemistry and Molecular Biology of Fishes. Elsevier, Amsterdam: 58-91.

Xu, Z., Dhar, A.K., Wyrzykowski, J., \& Alcivar-Warren, A. (1999), Identification of abundant and informative microsatellites from shrimp (Penaeus monodon) genome. Anim Genet, 30, 150- 156. doi: 10.1046/j.1365-2052.1999.00458.x

Yatabe, Y., Kane, N.C., Scotti-Saintagne, C., \& Rieseberg, L.H. (2007), Rampant geneexchange across a strong reproductive barrier between the annual sunflowers, Helianthus annuus and H. petiolaris. Genet, 175, 1883-1893. doi: 10.1534/genetics.106.064469.

Young, W.P., Wheeler, P.A., Coryell, V.H., Keim, P., Thorgaard, G.H. (1998), A detailed linkage map of rainbow trout produced using doubled haploids. Genet, 148, 839-850.

Yu, Z. N., \& Guo, X. M. (2003). Genetic linkage map of the eastern oyster Crassostrea virginica Gmelin. Biological Bulletin, 204(3), 327-338.

Yue, G.H., Y. Li, F. Chen, S. Cho, L.C. Lim and L. Orban : Comparison of three DNA marker systems for assessing genetic diversity in Asian arowana (Scleropages formosus). Electrophoresis, 23, 1025$1032 \quad$ (2002b) doi: 10.1002/15222683(200204)23:7/8<1025::AIDELPS1025>3.0.CO;2-Y

Yue, G. H. (2014). Recent advances of genome mapping and marker-assisted selection in aquaculture. Fish and Fisheries, 15(3), 376-396. doi: 10.1111/faf.12020.

Yue, H.-M., Li, Z., Wu, N., Liu, Z., Wang, Y., \& Gui, J.-F. (2013). Oocyte-specific H2A variant H2af1o is required for cell synchrony before midblastula transition in early zebrafish embryos. Biology of Reproduction,89(4),82. doi.org/10.1095/biolreprod.113.108043

Zhang, G., Breuer, M., Förster, A., Adam, D.E., \& Wodarzi, A. (2009), Mars, a Drosophila protein related to vertebrate HURP, is required for the attachment of centrosomes to the mitotic spindle during syncytial nuclear divisions. J Cell Sci, 122, 535-545. doi: 10.1242/jcs.040352. 